\title{
Augmentation of Urinary Lactoferrin Enhances Host Innate Immune Clearance of Uropathogenic Escherichia coli
}

\author{
Kathryn A. Patras ${ }^{a}$ Albert D. Ha ${ }^{a}$ Emma Rooholfada ${ }^{a}$ Joshua Olson ${ }^{a}$ \\ Satish P. Ramachandra Rao ${ }^{\text {b-d }}$ Ann E. Lin ${ }^{\text {a }}$ Victor Nizet ${ }^{\text {a, }}$ e \\ a Division of Host-Microbe Systems and Therapeutics, Department of Pediatrics, UC San Diego, La Jolla, CA, USA; \\ ${ }^{b}$ Department of Cellular and Molecular Medicine, UC San Diego, La Jolla, CA, USA; 'Division of Infectious \\ Diseases, Department of Medicine, UC San Diego, La Jolla, CA, USA; ${ }^{\mathrm{d} C e n t e r}$ for Clinical Research \& Education, \\ IAIM HealthCare Center, Yelahanka, India; eSkaggs School of Pharmacy and Pharmaceutical Sciences, \\ UC San Diego, La Jolla, CA, USA
}

\section{Keywords}

Lactoferrin - Urinary tract infection - Innate immunity . Neutrophil · Urine exosomes · Uropathogenic Escherichia coli

\section{Abstract \\ Urinary tract infection (UTI) is a prominent global health care burden. Although UTI is readily treated with antibiotics in healthy adults, complicated cases in immune-compromised individuals and the emerging antibiotic resistance of several uropathogens have accelerated the need for new treatment strategies. Here, we surveyed the composition of urinary exosomes in a mouse model of uropathgenic Escherichia coli (UPEC) UTI to identify specific urinary tract defense constitu- ents for therapeutic development. We found an enrichment of the iron-binding glycoprotein lactoferrin in the urinary exosomes of infected mice. In subsequent in vitro studies, we identified human bladder epithelial cells as a source of lactoferrin during UPEC infection. We further established that exogenous treatment with human lactoferrin (hLf) re- duces UPEC epithelial adherence and enhances neutrophil antimicrobial functions including bacterial killing and extra-}

cellular trap production. Notably, a single intravesicular dose of $h L f$ drastically reduced bladder bacterial burden and neutrophil infiltration in our murine UTI model. We propose that lactoferrin is an important modulator of innate immune responses in the urinary tract and has potential application in novel therapeutic design for UTI.

(C) 2019 The Author(s)

Published by S. Karger AG, Basel

\section{Introduction}

Urinary tract infection (UTI) afflicts more than half of women at least once in their lifetime and generates over $\$ 2.4$ billion in direct healthcare costs annually in the USA $[1,2]$. Acute UTI is most often mild and is readily treated in healthy adults, but elderly individuals or those with underlying metabolic and/or immune dysfunction such as diabetes mellitus, pregnancy, or multiple sclerosis are at risk for complications including recurrent UTI, pyelonephritis, or urinary obstruction [3-5]. UTI is the most common reason for prescribing antibiotics in primary care [6]. As a consequence, antibiotic resistance in urinary tract pathogens including the predominant caus- 
ative agent uropathogenic Escherichia coli (UPEC) is being increasingly recognized [7-10]. These circumstances are a cause for concern and drive a need to develop novel treatments for UTI beyond repeated antibiotics.

One strategy for novel therapeutic discovery entails identifying critical host urinary defenses that can be manipulated or enhanced. Urinary exosomes, extracellular membrane-bound vesicles present in urine [11], provide a physiologic "snapshot" of the cells lining the urinary tract and are thus an appealing, noninvasive source of both protein and RNA biomarkers for a variety of human urinary tract diseases $[12,13]$. Urinary exosomes are typically $40-100 \mathrm{~nm}$ in size and derive from the endocytic pathway with a "cytoplasmic-side in" orientation; they are further organized into multivesicular bodies released into the urinary space following fusion with the plasma membrane [12]. Many efforts have been made to establish the urinary exosome proteome in health [12] and in disease states such as polycystic kidney disease [14], Bartter syndrome type I [15], acute kidney injury [16], and various nephropathies [17]. Several physiologic roles of urinary exosomes have been proposed, including the elimination of aged proteins as an alternative to lysosomal degradation, and intercellular communication through the delivery of signaling molecules, mRNAs, and miRNAs [18]. Recently, human urinary exosomes were found to possess bactericidal activity against UPEC, in part due to a high concentration of antimicrobial proteins and peptides, suggesting that urinary exosomes contribute to the innate defense of the urinary tract [19].

Multiple host factors protect against UTI through direct or indirect antibacterial activity including antimicrobial peptides (cathelicidins and $\beta$-defensins), iron-binding proteins (lactoferrin and lipocalins), and soluble proteins that inhibit bacterial attachment (Tamm-Horsfall protein and secretory IgA) [20-25]. Many of these defense factors, including lactoferrin, lipocalin 1, lipocalin 2 , and $\beta$-defensin-9, have been detected in urinary exosomes of healthy humans [19]. Additionally, some of the associated antimicrobial peptides, including cathelicidin, can serve dual functions to recruit cellular immune responses during UTI [26]. Cellular innate immune responses to acute UTI include robust neutrophil recruitment and subsequent macrophage infiltration $[27,28]$. Neutrophil recruitment, in particular, is linked to control of the bacterial burden, reducing bacterial dissemination to the bloodstream, and limiting renal damage secondary to UTI $[29,30]$.

A principal objective of this study was to characterize the composition of urinary exosomes in the context of
UTI. To this end, we performed proteomic analyses of urinary exosomes collected from mice during UPEC UTI to probe host constituents involved in urinary tract defense. We identified lactoferrin as an abundant component of urinary exosomes during infection, and subsequently observed lactoferrin production by human bladder epithelial cells. Functional assays revealed a consistent protective effect of exogenous human lactoferrin (hLf) treatment against UPEC infection in coculture with human bladder epithelial cells and neutrophils, and the therapeutic potential of hLf was corroborated in a murine UPEC UTI model.

\section{Methods}

Bacterial Strains, Growth Conditions, and Minimum Inhibitory Concentration

Wild-type (WT) UPEC strain CFT073 (O6:K2:H1; ATCC 700928) was grown for at least $20 \mathrm{~h}$ in shaking culture to stationary phase at $37^{\circ} \mathrm{C}$ in Luria-Bertani (LB) broth prior to experiments. For growth curve and minimum inhibitory concentration (MIC) assays, overnight cultures were diluted 1:30 in fresh LB broth, and incubated by shaking at $37^{\circ} \mathrm{C}$ until mid-log phase $\left(\mathrm{OD}_{600 \mathrm{~nm}}=0.4\right)$. For growth curves, mid-log phase cultures were diluted 1:100 in synthetic urine [31] or RPMI-1640 containing 250, 125, 62.5, or 0 $\mu \mathrm{g} / \mathrm{mL}$ of lactoferrin from human milk (hLf, Sigma Aldrich, Cat\# L0520) or iron-saturated lactoferrin from human milk (Fe-Lf, Sigma Aldrich, Cat\# L3770). Bacterial growth was determined by $\mathrm{OD}_{600 \mathrm{~nm}}$ every $30-60 \mathrm{~min}$ for $7 \mathrm{~h}$, or by serial dilution and plating on LB agar at 1, 2, 4, 8, and $24 \mathrm{~h}$. For MICs, mid-log phase UPEC was diluted 1:100 in RPMI-1640. Diluted bacteria $(100 \mu \mathrm{L})$ were added to 96-well plates. hLf or Fe-Lf (2-fold dilution series, concentrations tested $0-1,000 \mu \mathrm{g} / \mathrm{mL}$ ) was diluted in RPMI-1640 and $100 \mu \mathrm{L}$ was added to the bacterial plates. The plates were then incubated at $37^{\circ} \mathrm{C}$ for $18 \mathrm{~h}$ and $\mathrm{OD}_{600 \mathrm{~nm}}$ was measured to determine MIC values.

\section{Animals}

Animal experiments were approved by the UC San Diego Institutional Animal Care and Use Committee (IACUC) and conducted under accepted veterinary standards. WT C57Bl/6J female mice, aged 7 weeks, were purchased from the Jackson Laboratory. HIF-1a knockout targeted to keratinocyte inactivation of HIF1a (Hif1 $\alpha^{\text {flox/flox }} / \mathrm{K} 14-\mathrm{Cre}^{+}$), and WT littermates (Hifl $\alpha^{\text {flox/flox }} / \mathrm{K} 14$ $\mathrm{Cre}^{-}$) from the same breeding pairs were used at 7-10 weeks [32]. Mice were allowed to eat and drink ad libitum.

\section{Cell Lines and Adherence Assays}

The human bladder epithelial cell line 5637 (ATCC\#, HTB-9) was cultured in RPMI-1640 (Gibco) media supplemented with $10 \%$ heat-inactivated $\mathrm{FBS}$ at $37^{\circ} \mathrm{C}$ in humidified air with $5 \% \mathrm{CO}_{2}$. Adherence assays were conducted as done previously [33] with a number of modifications. Briefly, HTB-9 monolayers in 24-well tissue culture plates were treated with $250 \mu \mathrm{g} / \mathrm{mL}$ hLf or Fe-Lf, or mock-treated for $2 \mathrm{~h}$ before adding CFT073 to cells at a multiplicity of infection (MOI) of 0.1 (CFT073-to-cell ratio). Plates were 
centrifuged at $300 \mathrm{~g}$ for $1 \mathrm{~min}$ and then incubated for $2 \mathrm{~h}$ at $37^{\circ} \mathrm{C}$ with $5 \% \mathrm{CO}_{2}$. Cells were washed 3 times with PBS, lysed, and plated on LB agar for enumeration.

\section{Generation of HIF-1 $\alpha$ Reporter Cells and Luciferase Assays}

HTB-9 cells at 70\% confluency in 24-well plates were transduced at MOI $=20$ with Cignal Lenti reporter mCMV-HRE-luciferase (CLS-007L), or Cignal Lenti control vector mCMV-luciferase (CLS-NCL) in combination with SureENTRY Transduction Reagent (Qiagen) at $8 \mu \mathrm{g} / \mathrm{ml}$ in RPMI- $1640+10 \%$ FBS. After $24 \mathrm{~h}$, lentiviral supernatant was removed and replaced with fresh media containing $0.5 \mu \mathrm{g} / \mathrm{mL}$ puromycin. Cell lines, termed HTB-9 HRE reporter cells and HTB-9 vector control cells, were selected after $48 \mathrm{~h}$ for puromycin resistance, with noninfected cells treated simultaneously to ensure proper selection. Cell lines were maintained in media supplemented with $0.5 \mu \mathrm{g} / \mathrm{mL}$ puromycin for population stability. For luciferase assays, HTB-9 HRE reporter and vector control cell monolayers in 96-well tissue culture plates were treated with $255 \mathrm{nM}$ AKB-4924 (Aerpio Pharmaceuticals), $300 \mu \mathrm{M}$ deferoxamine (DFO, Sigma Aldrich), and $250 \mu \mathrm{g} / \mathrm{mL} \mathrm{hLf}$, or mock-treated for $6 \mathrm{~h}$ in fresh RPMI- $1640+10 \% \mathrm{FBS}$ at $37^{\circ} \mathrm{C}$ with $5 \% \mathrm{CO}_{2}$. Cells were washed once with PBS and lysed with $25 \mu \mathrm{L} /$ well of Steady-Glo ${ }^{\circledR}$ Luciferase Assay System reagent (Promega) for 5 min at room temp. RPMI-1640, containing no phenol red or serum, was added $(25 \mu \mathrm{L} /$ well $)$, mixed, incubated at room temperature for $15 \mathrm{~min}$, and luminescence was then measured on an EnSpire Alpha Multimode Plate Reader (PerkinElmer). Arbitrary units (AU) of luminescence were normalized across individual experiments with mock-treated HRE reporter cells (range 25,000$60,000 \mathrm{AU})$. The range of luminescence detected in vector control cells in any treatment group was 100-4,000 AU and this was determined to be the assay background.

\section{Human Neutrophil Assays}

Under approval from UC San Diego IRB/HRPP, venous blood was obtained after informed consent from healthy adult volunteers, with heparin as an anticoagulant. Neutrophils were isolated using PolymorphPrep ${ }^{\mathrm{TM}}$ (Axis-Shield) to create a density gradient by centrifugation according to the manufacturer's instructions. For killing assays modified from previous work [34], neutrophils were diluted to $2 \times 10^{6}$ cells $/ \mathrm{mL}$ in RPMI-1640 (Gibco, Cat\# 11875-093), treated with $250 \mu \mathrm{g} / \mathrm{mL}$ of hLf or Fe-Lf, or mocktreated, and then incubated at $37^{\circ} \mathrm{C}$ in $5 \% \mathrm{CO}_{2}$ for $1 \mathrm{~h}$. Neutrophils were seeded at $2 \times 10^{5}$ cells/well in 96-well tissue culture plates. CFT073 diluted in RPMI-1640 was added to neutrophils at MOI = 0.1 . Plates were centrifuged at $300 \mathrm{~g}$ for $5 \mathrm{~min}$ to facilitate bacterial contact with neutrophils, and then incubated at $37^{\circ} \mathrm{C}$ in $5 \%$ $\mathrm{CO}_{2}$ for $30 \mathrm{~min}$. Samples were lysed, serially diluted, and then plated on LB agar for enumeration of the surviving colony-forming units (CFU). For reactive oxygen species (ROS) production, neutrophils were stained with $2^{\prime}, 7^{\prime}$-dichlorofluorescein diacetate (Sigma Aldrich), treated with $250 \mu \mathrm{g} / \mathrm{mL}$ of hLf or Fe-Lf, or mocktreated, and incubated at $37^{\circ} \mathrm{C}$ in $5 \% \mathrm{CO}_{2}$ for $1 \mathrm{~h}$ prior to the addition of $25 \mathrm{nM}$ phorbol 12-myristate 13-acetate (PMA, Sigma Aldrich) to stimulate ROS release [34]. Plates were incubated at $37^{\circ} \mathrm{C}$ with $5 \% \mathrm{CO}_{2}$ for $30 \mathrm{~min}$, and fluorescence intensity (485-nm excitation and 530-nm emission) was measured in an EnSpire Alpha Multimode Plate Reader (PerkinElmer). Samples were normalized to percent of fluorescence signal of the PMA-stimulated mock-treated controls. For quantification of neutrophil extracel- lular traps (NETs), isolated neutrophils were plated on 96-well tissue culture plates at $2 \times 10^{5}$ cells/well. Cells were pretreated with $250 \mu \mathrm{g} / \mathrm{mL}$ of hLf or Fe-Lf, or mock-treated, and incubated at $37^{\circ} \mathrm{C}$ in $5 \% \mathrm{CO}_{2}$ for $1 \mathrm{~h}$, and then incubated for an additional $3 \mathrm{~h}$ with PMA (25 nM) to induce NET production [35]. Micrococcal nuclease was then added at a final concentration of $500 \mathrm{mU} / \mathrm{mL}$ for 10 min to digest extracellular DNA. Plates were centrifuged at 200 $g$ for $8 \mathrm{~min}$; sample supernatant was then collected and transferred to a new 96-well plate. DNA was quantified using a Quant-iT PicoGreen ${ }^{\circledR}$ dsDNA Assay Kit from Life Technologies (Carlsbad, CA, USA).

\section{Murine Neutrophil Assays}

Neutrophils were isolated from the femurs and tibia of 7- to 8-week-old WT C57Bl/6J mice, as described previously [36] with minor modifications. Femurs and tibia were isolated and washed with ice-cold $70 \%$ ethanol and PBS, and then flushed with HBSS (Gibco, Cat\# 14175-095) with 0.1\% gelatin. The cells were centrifuged at $400 \mathrm{~g}$ for $5 \mathrm{~min}$ and resuspended in PBS. Neutrophils were isolated as described above. Neutrophils in $200 \mu \mathrm{L}$ HBSS (Gibco, Cat\# 14025-092) with 0.1\% gelatin and 2\% heat-inactivated FBS were seeded at $1-10 \times 10^{5}$ per well in 96 -well tissue culture plates. Cells were treated with $250 \mu \mathrm{g} / \mathrm{mL}$ of hLf or Fe-Lf, or mock-treated, and incubated at $37^{\circ} \mathrm{C}$ in $5 \% \mathrm{CO}_{2}$ for $1 \mathrm{~h}$. Cells were infected with CFT073 at $\mathrm{MOI}=0.1-2$. Plates were centrifuged at $400 \mathrm{~g}$ for $5 \mathrm{~min}$ to facilitate bacterial contact with the cells. After $45 \mathrm{~min}$, cells were lysed, serially diluted, and plated on LB agar to assess total surviving bacteria by CFU enumeration.

\section{Quantitative PCR}

For HTB-9 cells were infected at MOI $=0.1$ for $2 \mathrm{~h}$ with CFT073. Cell-to-Ct kit (Life Technologies) was used to isolate RNA, followed by cDNA synthesis using VILO polymerase (Life Technologies). After RNA isolates were resuspended in RNAase/DNasefree water, TURBO DNase (Ambion, Invitrogen) was added to eliminate potential DNase contamination in the RNA prep. To synthesize cDNA, approximately $100 \mathrm{ng}$ of total RNA was used for iScript cDNA synthesis kit (Bio-Rad), and approximately $1 \mathrm{ng}$ of cDNA was used in triplicates or quadruplicates for real-time quantitative (q)PCR using KAPA SYBR qPCR 2x master mix (KAPA Biosystem, Cat\# KM4101). The reaction was performed using the BioRad CFX96 real-time C1000 Thermocycler. Primers were used at a final concentration of $200 \mathrm{nmol}$. The primer sequences used for hLf were: (forward) $5^{\prime}$-ACG AAC TCA CTA TTA TGC CGG TTT T- $3^{\prime}$ and (reverse) $5^{\prime}$-CGG CAT AAT AGT GAG TTC GAC GGT G-3'). Human $\beta$-actin (forward: $5^{\prime}$-AAG AGA GGC ATC CTC ACC CT- $3^{\prime}$ and reverse: R $5^{\prime}$-TAC ATC GCT GGG GTG TTG- $3^{\prime}$ ) was used as a control house-keeping gene, and relative transcript level was normalized to endogenous $\beta$-actin using the 2- $\Delta \Delta \mathrm{Ct}$ method [37].

\section{Murine Urinary Tract Infection Model}

An established mouse UTI protocol was used as previously described [38]. Urine was voided from the bladder prior to transurethral treatment with $100 \mu \mathrm{g}$ of hLf (Sigma Aldrich, Cat\# L0520) in $100 \mu \mathrm{L}$ (administered in approx. $4 \mathrm{~s}$ ), or mock-treated with $100 \mu \mathrm{L}$ of PBS, for $1 \mathrm{~h}$ followed by infection with $50 \mu \mathrm{L}$ of UPEC CFT073 (administered in approx. 2-3 s) at $2-3 \times 10^{7} \mathrm{CFU}$ per mouse. Transurethral infection was achieved by inserting a UV-sterilized polyethylene tube (inner dimension $0.28 \mathrm{~mm}$ and outer dimension 
$0.61 \mathrm{~mm}$, Cat\# 598321 Harvard Apparatus) attached to a 30-g hypodermic needle into the urethra. At $24 \mathrm{~h}$ after infection, urine samples were collected from each mouse. Bladders and both kidneys were removed and homogenized in PBS using a MagNa Lyser (Roche), and serially diluted and plated on LB agar for CFU enumeration.

\section{Exosome Isolation}

Urine from CFT073-infected or mock-infected mice $24 \mathrm{~h}$ after infection ( $n>10$ per group) was pooled and centrifuged at $3,000 \mathrm{~g}$ for $10 \mathrm{~min}$ at $4{ }^{\circ} \mathrm{C}$. For cell culture, HTB- 9 cells were infected with CFT073 at MOI $=20$ for $2 \mathrm{~h}$ or mock-infected, and supernatants were removed and centrifuged at $3,000 \mathrm{~g}$ for $10 \mathrm{~min}$ at $4{ }^{\circ} \mathrm{C}$. The supernatant was removed and mixed with urinary exosome isolation buffer (Life Technologies) at a 1:1 ratio (v/v). The mixture was shaken at room temperature for $1 \mathrm{~h}$, followed by centrifugation at $10,000 \mathrm{~g}$ for $30 \mathrm{~min}$. The supernatant was removed, and the precipitating proteins were reconstituted in $30-50 \mu \mathrm{L}$ of PBS.

\section{SDS-PAGE and Western Blot}

SDS-PAGE and Western blot assays were performed as described previously [39]. Protein concentrations from murine urine exosomes and HTB-9 cell exosomes were measured by Bradford protein binding colorimetric assay (Bio-Rad), and samples were loaded on a precasted $4-12 \%$ SDS polyacrylamide gel (Bio-Rad). For protein band visualization, gels were stained with Simply Blu$\mathrm{e}^{\mathrm{TM}}$ Safe Stain (Thermo Fisher). To probe for lactoferrin in HTB-9 exosomes, the following antibodies were used: goat anti-lactoferrin antibody at 1:500 (Santa Cruz Biotechnology, Cat\# sc-14434) and anti- $\beta$-actin monoclonal antibody at 1:2,000 (Clone AC-74, Sigma Aldrich, Cat\# A5316).

\section{Liquid Chromatography-MS/MS Analysis}

Gel tracks from Coomassie-stained gels were separated into 3 equal sections and submitted to the UCSD Biomolecular and Proteomics Mass Spectrometry Facility for liquid chromatography tandem mass spectrometry (LC-MS/MS) analysis. Samples were trypsin-digested and subjected to LC-MS/MS as described previously [40]. Four independent experiments were performed on 4 MS runs, and data from these runs were combined. Protein identification required $\geq 2$ unique peptides, with a false discovery rate of 0.1. Normalized spectral abundance factor (NSAF) was calculated using the formula established previously [41]. Gene ontology analyses and accompanying graphics were performed on ranked NSAF values of UPEC-infected mice using the Gene Ontology Enrichment Analyses and Visualization Tool (GOrilla) $[42]$.

\section{Flow Cytometry}

Urine samples were subjected to flow cytometry as described previously [34]. Urine was passed through a $40-\mu \mathrm{m}$ filter, and cells were then washed in PBS and blocked with $2 \%$ FBS for 15 min on ice. Staining of surface markers was performed in $2 \%$ FBS using 0.5 $\mu \mathrm{g} / \mathrm{mL}$ anti-CD11b-FITC (Clone M1/70, Cat\# 553310, BD Pharmingen) and anti-Ly6G-APC (Clone 1A8, Cat\# 127614, BioLegend) for $30 \mathrm{~min}$ on ice. Samples were gated on unstained cells and positive signals were determined using single-stain controls. Samples were run on BD FACSCantoII (BD Biosciences) and data were analyzed with FlowJo v10.2 software (FlowJo LLC).
ELISAs

HTB-9 lysates were assessed for lactoferrin production using an hLf ELISA kit (Abcam, Cat\# ab200015) per manufacturer's instructions. Murine bladder homogenates were diluted 1:2 and subjected to lactoferrin quantification using a mouse lactoferrin ELISA kit (LSBio, Cat\# LS-F4352) as per the manufacturer.

\section{Statistical Analyses}

All data were collected from at least 3 biological replicates performed in at least technical duplicate as part of at least 2 independent experiments. When biological replicates were not available (e.g., immortalized cell lines and bacteria-only assays), experiments were performed independently at least 3 times. Mean values from technical replicates were used for statistical analyses, with independent experiment values or biological replicates represented in graphs with mean \pm SEM or median and $95 \%$ confidence interval (CI). All datasets were subjected to the D'Agostino and Pearson normality test to determine whether values displayed Gaussian distribution before selecting the appropriate parametric or nonparametric analyses. Data from growth curves were assumed to be parametric. In the instances where in vitro, ex vivo, and in vivo experimental numbers were too small to determine normality, data were assumed to be nonparametric. The level $\alpha=$ 0.05 was used for all tests. NSAF values from LC-MS/MS, nonparametric continuous variables, were analyzed using the Wilcoxon matched-pairs signed rank test. HTB-9 mRNA expression and murine bladder lactoferrin ELISA were analyzed using the twotailed Mann-Whitney U test. UPEC adherence to HTB-9 cells, HTB-9 lactoferrin ELISA, and HRE reporter cell bioluminescence were analyzed using one-way ANOVA with the Holm-Sidak or Tukey multiple comparisons test. Human neutrophil killing was analyzed using the Kruskal-Wallis test with the Dunn multiple comparisons test. UPEC growth curves, human NETs and ROS, bladder and kidney CFU, and urine cell populations were analyzed using two-way ANOVA with the Tukey or Sidak multiple comparisons test. Murine neutrophil killing was analyzed using the two-tailed paired Student $t$ test. Statistical analyses were performed using GraphPad Prism, v7.03 (GraphPad Software Inc., La Jolla, CA, USA). $p<0.05$ was considered statistically significant.

\section{Results}

\section{UPEC Increases the Release of Lactoferrin in Urinary Exosomes}

To assess changes to the proteomic content of urinary exosomes during acute UTI, female C57Bl/6 mice, $7-8$ weeks of age, were infected transurethrally with $1 \times 10^{7}$ CFU of UPEC strain CFT073, or mock-infected as a control. At $24 \mathrm{~h}$ postinfection, urine was collected, pooled, and urinary exosomes isolated as described in Methods. Analysis of 4 independent LC-MS/MS runs with urinary exosomes of pooled mouse samples ( $>10$ mice/group) detected a total of 650 proteins (online suppl. Table 1; see www.karger.com/doi/10.1159/000499342 for all online suppl. material); 302 proteins were unique to UPEC-in- 


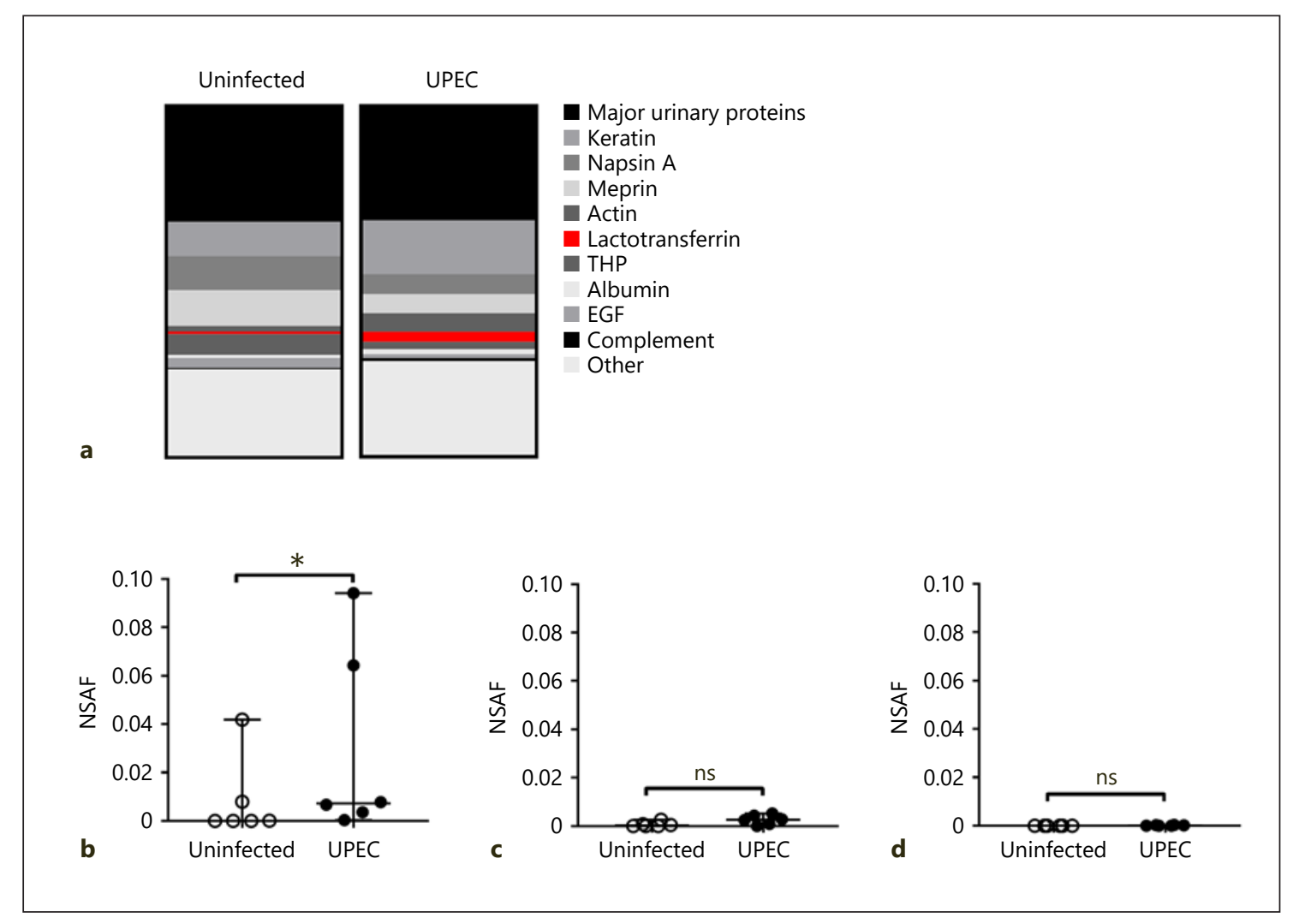

Fig. 1. Urinary exosome lactoferrin is significantly increased during UPEC infection. a Proportion of proteins or protein families detected in urinary exosomes of UPEC-infected WT C57Bl/6 mice $24 \mathrm{~h}$ postinfection with $2-3 \times 10^{7} \mathrm{CFU}$ CFT073 or uninfected controls. Data represent the combined results of 4 independent experiments and LC-MS/MS runs (6 independent pooled urine sam-

fected mice, and 55 were unique to uninfected controls. Gene ontology analyses of ranked proteins in infected mice demonstrated a significant enrichment of the cellular components of the plasma membrane, cytoskeletal fibers, and keratin filaments (online suppl. Fig. 1) and of biological processes including keratinization, cytoskeleton organization, and humoral immune responses (online suppl. Fig. 2). Of the 10 most abundant proteins or protein families detected (representing $73 \%$ of proteins detected in UPEC-infected mice and $75 \%$ of proteins in uninfected controls), UPEC-infected mice displayed reduced levels of renal proteins including napsin A, meprin, epithelial growth factor (EGF), and an expansion in complement system proteins (including $\mathrm{C} 3$, factor $\mathrm{B}$, and factor $\mathrm{H}$ ) and lactoferrin (Fig. 1a). Common urinary exosome contaminants including Tamm-Horsfall protein (THP), albumin, and mouse-specific major urinary pro- ples, $n>10$ /group). Normalized spectral abundance factor (NSAF) of lactoferrin (b), myeloperoxidase (c), and neutrophil elastase (d) from the same LC-MS/MS experiments as in a. Symbols represent 6 independent pooled biological replicates/group with lines indicating median and $95 \%$ CI. b-d Data were analyzed with the Wilcoxon matched-pairs signed rank test. ${ }^{*} p<0.05$. teins (MUP1-4) were also detected [43]. Comparison of the NSAF demonstrated a significant increase of lactoferrin in UPEC-infected mice (mean uninfected NSAF = 0.0083 , mean UPEC-infected NSAF $=0.0295, p=0.0313$ ) (Fig. 1B). Because lactoferrin is abundant in the secondary granules of neutrophils [44], we also examined the relative abundance of the neutrophil-associated proteins myeloperoxidase (MPO) and neutrophil elastase. Interestingly, although MPO (mean uninfected NSAF = 0.0007 , mean UPEC-infected NSAF $=0.0026, p=0.0625$ ) and elastase (mean uninfected NSAF $=0.0000$ [not detected], mean UPEC-infected NSAF $=0.0002, p=0.1250$ ) were higher in UPEC-infected mice, their relative proportions were much lower than that of lactoferrin (Fig. 1c, d). 


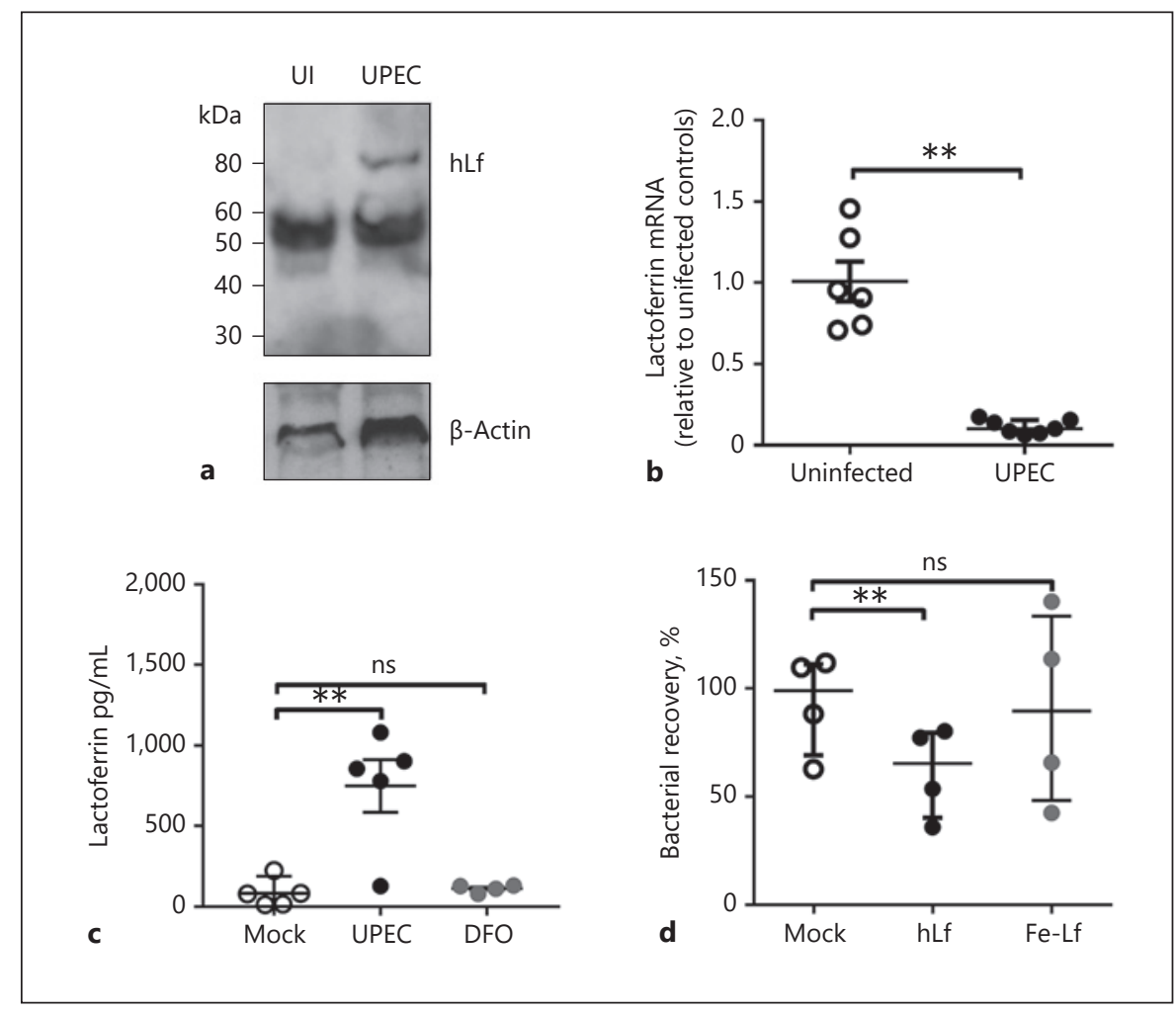

Fig. 2. Bladder epithelial cells produce lactoferrin in response to UPEC infection. a Western blot of exosomes from HTB-9 cells infected with CFT073 for $2 \mathrm{~h}$, MOI of 20, and probed for human lactoferrin (approx. $80 \mathrm{kDa}$, top image) and $\beta$-actin (bottom image) as a loading control. A single representative blot from 3 independent experiments is shown. b Normalized lactoferrin mRNA from HTB-9 cells infected with CFT073 for $2 \mathrm{~h}$, MOI of 0.1 , as quantified by qPCR. Symbols represent $6-7$ independent replicates/group, with lines indicating mean \pm SEM. c Lactoferrin production in HTB-9 cell lysate infected with CFT073, MOI of 0.1, or treated with deferoxamine (DFO, $300 \mu \mathrm{M})$ for $4 \mathrm{~h}$ as quantified by ELISA. Symbols represent means of independent experiments $(n=4-5)$ with lines indicating mean \pm SEM. $\mathbf{d}$ Percent adherence of CFT073 to HTB-9 cells after 30 min of infection, MOI $=0.1$. Symbols represent means of independent experiments $(n=4$ / group) with lines indicating mean \pm SEM. Data were analyzed using the two-tailed Mann-Whitney U test (b), or one-way ANOVA with the Holm-Sidak multiple comparisons test $(\mathbf{c}, \mathbf{d}) .{ }^{* *} p<0.01$. hLf, human lactoferrin; Fe-Lf, iron-saturated lactoferrin.
UPEC Stimulates the Production of Lactoferrin in Bladder Epithelial Cells

Due to the abundance of lactoferrin in UPEC-infected mice (Fig. 1), we examined whether the bladder epithelium itself could be a source of lactoferrin during UTI. Monolayers of HTB-9 cells were infected with UPEC CFT073 for $2 \mathrm{~h}$, and exosomes were isolated and analyzed for lactoferrin via Western blot. In UPEC-infected HTB9 exosomes, a band of approximately $80 \mathrm{kDa}$ was detected with an $\alpha$-lactoferrin antibody, but no band was visualized in uninfected controls (Fig. 2a). HTB-9 samples were also subjected to lactoferrin mRNA analyses, and although lactoferrin transcripts were detected under both conditions, UPEC-infected cells demonstrated a significant reduction (9-fold, $p=0.0012$ ) in lactoferrin mRNA transcripts compared to uninfected controls (Fig. 2b). To quantify the total amount of lactoferrin produced by HTB-9 cells during UPEC infection, these were infected for $4 \mathrm{~h}$, lysed, and then lactoferrin was quantified by ELISA. To test whether the iron limitation induced by UPEC infection was a stimulus for lactoferrin production, deferoxamine (DFO, $300 \mu \mathrm{M})$, an iron chelator, was included as a control. Lysate from UPEC-infected HTB-9 cells contained significantly higher levels of lactoferrin (mean $=$ $749 \mathrm{pg} / \mathrm{mL}$ ) than uninfected controls (mean $=83 \mathrm{pg} / \mathrm{mL}$, $p=0.0021$ ) (Fig. 2c). DFO treatment did not induce greater lactoferrin production than in uninfected controls ( mean $=112 \mathrm{pg} / \mathrm{mL}, p=0.8509)$. To determine if exogenous lactoferrin alters HTB-9 cell responses to UPEC, these cells were treated with $250 \mu \mathrm{g} / \mathrm{mL}$ native lactoferrin 


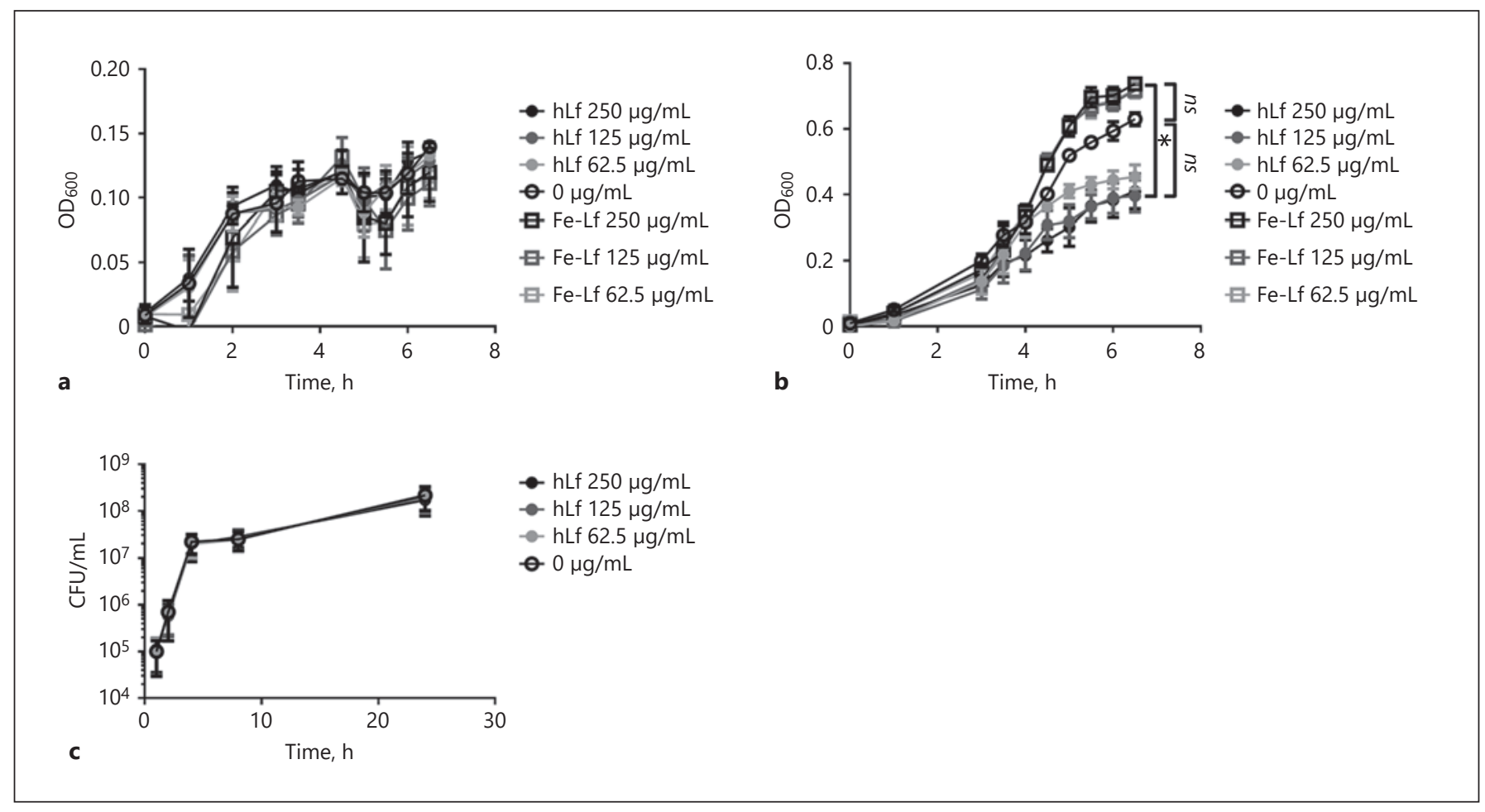

Fig. 3. Human lactoferrin is not antimicrobial in synthetic urine. Growth curves of CFT073 in synthetic urine (a) or RPMI-1640 (b) with given concentrations of hLf and Fe-Lf as measured by optical density (OD). c Viable CFU/mL in RPMI-1640 were measured by serial dilution and plating. Symbols represent the means of independent experiments ( $n=3-4$ /group) with lines indicating mean \pm SEM. All data were analyzed using two-way ANOVA with the Tukey multiple comparisons test. ${ }^{*} p<0.05$. isolated from human milk, i.e., hLf, overnight, and then UPEC adherence was measured after $2 \mathrm{~h}$ infection. Fe-Lf was included as a control for the effects of lactoferrinmediated iron chelation in the experimental conditions. Pretreatment with hLf (approx. 10\% iron-saturated, 2097325) significantly reduced UPEC adherence compared to in mock-treated controls (mean adherence 61.8 and $93.2 \%$ respectively, $p=0.0015)$. Pretreatment with Fe-Lf ( $>90 \%$ iron-saturated) did not reduce UPEC adherence compared to in mock-treated controls (mean adherence $90.5 \%, p=0.9070$ ) (Fig. $2 \mathrm{~d}$ ).

\section{hLf Is Not Directly Antimicrobial in Synthetic Urine}

To test the antimicrobial activity of hLf and Fe-Lf against UPEC, bacterial growth curves were performed in synthetic human urine [31] and tissue culture medium RPMI-1640 during $7 \mathrm{~h}$ of culture. Neither hLf nor Fe-Lf altered the growth of UPEC in synthetic urine at concentrations of 250,125 , or $62.5 \mu \mathrm{g} / \mathrm{mL}$ (Fig. 3a). In RPMI1640 , no significant differences in growth were observed between $\mathrm{hLf}(p=0.0749)$ or Fe-Lf $(p=0.7912)$ conditions and controls; however, a small but significant growth advantage was observed in the bacteria grown in Fe-Lf (all concentrations) compared to those grown in 250 and 125 $\mu \mathrm{g} / \mathrm{mL}$ of hLf (Fig. 3b). To establish if hLf treatment altered bacterial viability, UPEC was grown in RPMI-1640 containing $250,125,62.5$, or $0 \mu \mathrm{g} / \mathrm{mL} \mathrm{hLf}$, and viable CFU were determined via plating at $1,2,4,8$, and $24 \mathrm{~h}$. No significant differences were observed in CFU across all conditions (Fig. 3c). The MIC for hLf and Fe-Lf was $>1 \mathrm{mg} /$ $\mathrm{mL}$ in both synthetic urine and RPMI-1640 (data not shown).

\section{hLf Promotes Neutrophil-Mediated Bacterial Killing}

Since neutrophils are a known source of lactoferrin [44] and are important early innate effectors during UTI [29], we examined the effect of exogenous lactoferrin on neutrophil antibacterial functions. Primary human neutrophils were isolated from human blood, pretreated with $250 \mu \mathrm{g} / \mathrm{mL}$ hLf or Fe-Lf for $1 \mathrm{~h}$, and then incubated with UPEC at a MOI of 0.1 for $30 \mathrm{~min}$. Treatment with either hLf or Fe-Lf significantly reduced bacterial survival com- 


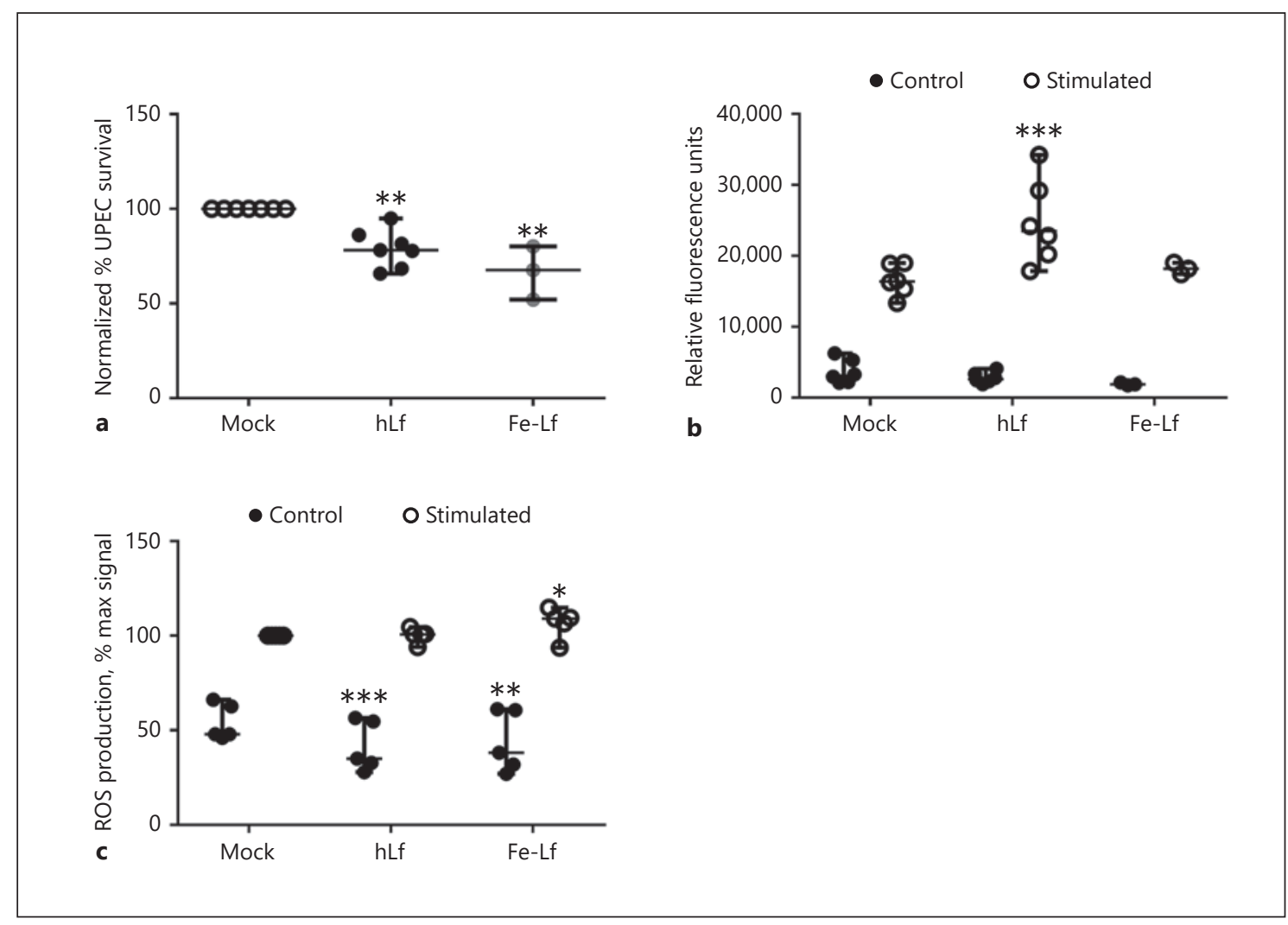

Fig. 4. Exogenous lactoferrin alters neutrophil antimicrobial functions. Isolated human neutrophils were pretreated with $250 \mu \mathrm{g} / \mathrm{mL}$ hLf or Fe-Lf as indicated in Methods. a Neutrophil killing of CFT073 expressed as a percentage of inoculum and normalized to mock-treated controls within biological replicates. b Neutrophil extracellular trap (NET) formation by production by unstimulated neutrophils (control), or neutrophils stimulated with PMA as measured by fluorescence. c Reactive oxygen species (ROS) production by unstimulated neutrophils (control) or neutrophils

pared to mock-treated controls (mean normalized $\mathrm{hLf}=$ $79.0 \%$ and $\mathrm{Fe}-\mathrm{Lf}=66.7 \%, p<0.01$ ) (Fig. $4 \mathrm{a}$ ). The formation of NETs was determined by stimulation with PMA in the presence of $250 \mu \mathrm{g} / \mathrm{mL}$ hLf or Fe-Lf over $4 \mathrm{~h}$, and extracellular double-strand DNA release was quantified via fluorescence. In PMA-stimulated neutrophils, treatment with hLF significantly increased NET generation compared to that in mock-treated controls (mean 22,840 and 16,794 relative fluorescence units [RFU], respectively; $p=0.0038)$, but no difference was observed in stimulated cells treated with Fe-Lf (mean 18,210 RFU; $p=$ 0.9624) (Fig. 4b). No differences were observed in control neutrophils not stimulated with PMA. In a similar manner, ROS production of human neutrophils was measured in the absence or presence of stimulation with stimulated with PMA and normalized to maximum values of mock-treated stimulated neutrophils within biological replicates. Symbols represent the means of biological replicates $(n=3-7 /$ group), with lines indicating median and 95\% CI. Data were analyzed using the Kruskal-Wallis test with the Dunn multiple comparisons test (a), or two-way ANOVA with the Sidak multiple comparisons test (b, c). ${ }^{* * *} p<0.01,{ }^{* *} p<0.01,{ }^{*} p<0.05$ compared to mock-treated cells within the group (i.e., control or stimulated). hLf, human lactoferrin; Fe-Lf, iron-saturated lactoferrin.

PMA. In PMA-stimulated neutrophils, treatment with Fe-LF generated a slight but significant increase in ROS over that in mock-treated controls (mean \% of max signal $=107 \% ; p=0.0492)$, but no difference was observed in stimulated cells treated with hLf (mean \% of max signal $=100 \% ; p=0.9998$ ) (Fig. 4c). In unstimulated controls, both hLf (mean \% of max signal $=41 \% ; p=0.0003$ ) and Fe-Lf (mean $\%$ of $\max$ signal $=44 \% ; p=0.0025$ ) treatment suppressed ROS compared to in mock-treated cells $($ mean $\%$ of $\max$ signal $=54 \%)($ Fig. $4 \mathrm{c})$.

\section{Exogenous Lactoferrin Enhances Clearance of UPEC} in vivo

To characterize the effect of exogenous lactoferrin in vivo, we first confirmed hLf enhancement of UPEC kill- 


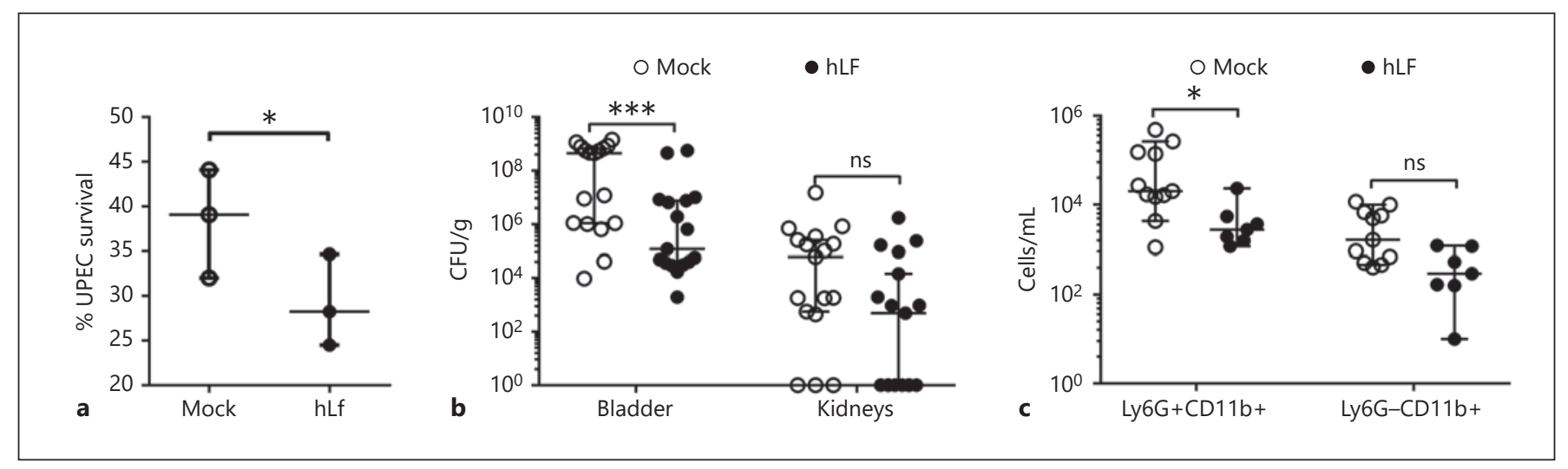

Fig. 5. Exogenous lactoferrin protects against UPEC UTI in vivo. a Bone marrow-derived murine neutrophils were pretreated with $250 \mu \mathrm{g} / \mathrm{mL}$ hLf and killing of CFT073 was expressed as a percentage of inoculum. Symbols represent the means of biological replicates ( $n=3$ /group), with lines indicating median and 95\% CI. WT C57Bl/6 mice were transurethrally treated with hLf $1 \mathrm{~h}$ prior to infection with 2-3 $\times 10^{7}$ CFU CFT073, or mock-treated as a control. b Bladder and kidney bacterial burdens quantified $24 \mathrm{~h}$ postinfection. c Ly6G+/CD11b+ and Ly6G-/CD11b+ cells in mouse urine collected $24 \mathrm{~h}$ postinfection and quantified via flow cytometry. Symbols represent biological replicates $(n=7-17 /$ group), with lines indicating median and 95\% CI. Data were analyzed using the two-tailed paired Student $t$ test (a) or two-way ANOVA with the Sidak multiple comparisons test (b, c). ${ }^{* * *} p<$ $0.01, * p<0.05$. ing by murine neutrophils. Neutrophils were harvested from the bone marrow of WT $\mathrm{C} 57 \mathrm{Bl} / 6$ mice, pretreated with $250 \mu \mathrm{g} / \mathrm{mL}$ hLf for $1 \mathrm{~h}$, and then incubated with UPEC at a MOI of 0.1 for $45 \mathrm{~min}$. Pretreatment with hLf significantly reduced bacterial survival compared to mock-treated controls (a mean survival of 38.4 and $29.1 \%$, respectively; $p=0.0105$ ) (Fig. $5 \mathrm{a}$ ). To test the effect of lactoferrin in a murine UTI model, WT C57Bl/6 mice received a single transurethral dose of hLf $(100 \mu \mathrm{g}$ in $50 \mu \mathrm{L}$ of PBS); $1 \mathrm{~h}$ later, they were infected with $2 \times$ $10^{7} \mathrm{CFU}$ of UPEC CFT073 in $50 \mu \mathrm{L}$ of PBS. Urine, bladder, and kidneys were collected $24 \mathrm{~h}$ postinfection. Mice treated with hLf exhibited a $>1,000$-fold reduction in bladder CFU (median $1.19 \times 10^{5} \mathrm{CFU} / g$ vs. $4.48 \times 10^{8}$ $\mathrm{CFU} / \mathrm{g}$ in mock-treated mice; $p=0.0002$ ), but no significant differences were observed in kidney CFU (median $4.97 \times 10^{2} \mathrm{CFU} / \mathrm{g}$ and $6.08 \times 10^{4} \mathrm{CFU} / \mathrm{g}$, respectively; $p=0.9999$ ) (Fig. 5b). Cells isolated from urine were stained for CD45, Ly6G, and CD11b, and then analyzed via flow cytometry. Mice treated with hLf exhibited a significant reduction in Ly6G+CD11b+ (neutrophil) populations (median $2.78 \times 10^{3}$ cells $/ \mathrm{mL}$ vs. $2.02 \times$ $10^{4}$ cells/mL in mock-treated mice; $p=0.0452$ ), but no significant differences were observed in Ly6G-CD11b+ (other myeloid cells) populations (median $2.93 \times 10^{2}$ cells $/ \mathrm{mL}$ and $1.65 \times 10^{3}$ cells $/ \mathrm{mL}$, respectively; $p=$ 0.9955) (Fig. 5c).
Exogenous Lactoferrin Does Not Alter HIF-1 $\alpha$

Stabilization in Bladder Epithelial Cells

It has been proposed that iron chelation effects of lactoferrin serve as a physiologic mimetic of hypoxia. Systemic administration of lactoferrin stabilizes the transcription factor hypoxia-inducible factor (HIF)- 1 a which, during normoxia, is rapidly degraded upon modification by iron-sensitive hydroxylases [45]. We previously demonstrated that HIF-1 1 stabilization during UPEC UTI reduced bacterial burden, proinflammatory cytokines, and neutrophil activation markers [38]. To investigate if exogenous lactoferrin alters HIF-1a levels in human bladder epithelial cells, we generated HTB-9 mCMV-HREluciferase reporter cells. A 6-h treatment of HTB-9 HRE reporter cells with $255 \mathrm{nM}$ of AKB-4924, a prolylhydroxlase inhibitor (a 1.65-fold increase, $p=0.0072$ ) [46], and $300 \mu \mathrm{M}$ of DFO (a 1.65-fold increase, $p=0.0457$ ), but not $250 \mu \mathrm{g} / \mathrm{mL}$ hLf (no change, $p>0.9999$ ), significantly increased luciferase signal over that in mock-treated controls (online suppl. Fig. 3A). On the other hand, treatment of AKB-4924 (mean $197 \mathrm{pg} / \mathrm{mL}$ ) did not significantly alter endogenous production of lactoferrin by HTB-9 cell lysate compared to vehicle and mock-treated controls (mean 81 and $70 \mathrm{pg} / \mathrm{mL}$, respectively; online suppl. Fig. 3B). Additionally, although mice with a Cre recombinase-mediated, keratinocyte-specific inactivation of HIF-1a (Hifla $1 /$ l/fl/K14-Cre+ $)$ are more susceptible to UPEC UTI [38], endogenous bladder levels of lactoferrin 
(median $133 \mathrm{ng} / \mathrm{g}$ ) were not altered $24 \mathrm{~h}$ postinfection compared to littermate Hifl $\alpha^{\mathrm{fl} / \mathrm{fl}} / \mathrm{K} 14$-Cre- control mice (median $194 \mathrm{ng} / \mathrm{g} ; p=0.0973$; online suppl. Fig 3C).

\section{Discussion}

A major objective of this study was to investigate the composition of urinary exosomes during UPEC UTI in a murine model to identify host defense constituents. Very few studies have been conducted on urinary exosomes in mice [47-49] and none has performed nontargeted proteomic analyses. Urinary exosome proteomic analyses have been conducted in a variety of human disease states including those affecting the bladder, kidneys, and even remote organs including the lung [50], but, to our knowledge, the composition of urinary exosomes during UTI has not been characterized. More than one-third of the proteins we detected were previously reported in human urinary exosome studies (online suppl. Table 1, indicated by grey shading) suggesting moderate species conservation and suitable application of murine models to describe urinary exosome components. These proteins include ALIX and TSG101 (ESCRT components and binding partners), Rab and Rho family members, cytoskeletal and motor proteins, and multiple integral membrane proteins characteristic of urinary exosomes [12, 19]. However, more than half of the proteins detected in our analyses have not been previously identified in human studies. This may be due to species-specific proteins (including major urinary proteins which are absent in humans), proteins from infiltrating immune cells (neutrophils, eosinophils, and other lymphocytes) and, lastly, proteins from the urinary tract epithelium specific to host response during UTI.

One such protein, lactoferrin, has been previously detected in human urinary exosomes of healthy subjects [19]. In this study, we found an expansion of lactoferrin in UPEC-infected mice, comprising around 3\% of protein detected in urinary exosomes compared to $<1 \%$ of protein in uninfected controls (Fig. 1). Lactoferrin is a cationic transferrin with a high affinity for iron that is secreted by a variety of glandular and epithelial tissues and is a predominant component of human breastmilk (2-7 $\mathrm{g} / \mathrm{L}$ [51]). It has historically been associated with iron absorption in nursing newborns; however, a more recent study using lactoferrin-deficient mice indicated that lactoferrin is not required for iron uptake nor are there differences in iron delivery or tissue iron stores compared to WT mice [52]. In the urinary tract, lactoferrin serves as a biomarker for UTI with a 100 -fold increase compared to healthy controls $[53,54]$, but the source of lactoferrin during infection has not been fully characterized. Infiltrating neutrophils [51], as well as renal collecting tubules [55] may be sources of urinary lactoferrin, and we could not rule out these sources in our study. Of note, we found that HTB-9 cells produced lactoferrin mRNA transcripts in both control and UPEC-infected cells. However, the discordant levels of mRNA and protein in our analyses suggest that lactoferrin is posttranscriptionally regulated in the bladder epithelium (Fig. 2). Lactoferrin production has previously been detected in another urothelial cell line (HCV29) and was found to decrease upon infection with the parasite Schistosoma haematobium [56]. We conclude that urinary lactoferrin comes most likely from a combination of cellular sources, particularly during UTI.

The physiologic role of lactoferrin during UTI is not fully understood. Its antimicrobial activity against a variety of human bacterial, viral, and fungal pathogens is widely recognized [57]. At some sites, it achieves relatively high concentrations, e.g., $1.1 \mu \mathrm{g} / \mathrm{mL}$ in saliva [58], $1.7 \mu \mathrm{g} / \mathrm{mL}$ in cervical-vaginal lavage [59], or $2.2 \mathrm{mg} / \mathrm{mL}$ in tears [60]. In other body fluids, baseline levels are relatively low, e.g., $123 \mathrm{ng} / \mathrm{mL}$ in plasma [61] and 30-75 ng/ $\mathrm{mL}$ in human urine $[53,55]$. In bacterial infections, the level may rise to as high as $2 \mu \mathrm{g} / \mathrm{mL}$ in plasma during sepsis [61], $3 \mu \mathrm{g} / \mathrm{mL}$ in urine during UTI [53], or $5 \mu \mathrm{g} / \mathrm{mL}$ in vaginal secretions during bacterial vaginosis [59]. Most of these physiologic concentrations are well below the MIC that is required for bacterial $(130 \mu \mathrm{g} / \mathrm{mL}$ to $5 \mathrm{mg} / \mathrm{mL})$ [62-65] and fungal $(200 \mu \mathrm{g} / \mathrm{mL}-100 \mathrm{mg} / \mathrm{mL})$ pathogens $[66,67]$, suggesting that the antimicrobial activity of lactoferrin, through iron sequestration or microbial membrane disruption, may not be its primary role in numerous body fluids including the urine. At higher concentrations, such as that present in human milk and tears and infant urine, its antimicrobial activity may indeed play an important role in the modulation of host defenses. In this study, lactoferrin did not appear to be antimicrobial in synthetic urine (Fig. 3), which is a nutrient-poor condition. In tissue-culture media, native hLf was modestly more effective in reducing UPEC growth than Fe-Lf (measured by optical density), a phenomenon also observed with Candida [68], but no reduction in CFU viability was observed under our conditions. Additional factors impacting differences in optical density may include changes to bacterial pigmentation or capsule thickness, although no alterations of bacterial buoyancy, a measurement of capsular expression, were observed under the ex- 
perimental conditions (data not shown). It is also possible that lactoferrin synergizes with other host proteins to maximize antimicrobial activity at physiologic concentrations, an effect which would have been missed in our in vitro assays. For subsequent studies investigating the impact of lactoferrin on neutrophils and bladder epithelial cell function, we tested the level of $250 \mu \mathrm{g} / \mathrm{mL}$ lactoferrin, which is at the upper limit of lactoferrin detected in the urine of breastfed infants [69]. We postulate that this may be a physiologically achievable concentration in individuals taking oral lactoferrin supplements, as bovine lactoferrin delivered orally has demonstrated a $>60 \%$ gastric survival in healthy adults [70].

We observed a reduction in UPEC adherence to human bladder epithelial cells, a phenomenon observed previously in other in vitro models. Treatment with hLf reduced the adherence of enteropathogenic E. coli (EPEC) to HELA cells [71], and treatment with bovine lactoferrin reduced the adherence of Streptococcus dysgalactiae to mammary epithelial cells [72]. More generally, lactoferrin coating of glass surfaces reduces adherence of Pseudomonas aeruginosa and Staphylococcus aureus [73]. The mechanism by which bacterial adhesion to the bladder is blocked by hLf remains to be determined, and it is possible that hLf acts either through host-bacterial receptor antagonism as seen previously with E. coli 055:B5 [74] and S. uberis [75] or through lactoferrin-mediated altered bacterial aggregation/dispersion [76]. hLf did not inhibit the adherence of UPEC to mouse uroepithelial cells [77], suggesting the potential for species specificity. Of note, Fe-Lf did not have an impact on UPEC adherence to bladder epithelial cells, suggesting a role of iron sequestration by lactoferrin in reduced cellular adherence.

Emerging evidence establishes lactoferrin, also a factor of neutrophil secondary granules, as a potent immune modulator including the suppression of the proinflammatory cytokines TNF- $\alpha$, IL-1 $\beta$, IL-6, and IL-8 [78-80], the transcriptional regulation in whole blood, NK cells, and macrophages $[80,81]$, the reduction of apoptosis in monocytes [82, 83], and increased macrophage intracellular killing [84]. In this study, we focused on the effect of exogenous hLf on neutrophil antibacterial functions. Several earlier studies examined the effect of hLf or lactoferrin fragments on neutrophil function, and they reached differing conclusions. Results included the lactoferrinmediated enhancement $[85,86]$ or inhibition [87] of NET production, the suppression of $[88,89]$, augmentation of [90], or no impact [87] on ROS formation, the delay of apoptosis [91], and no effect on neutrophil phagocytosis $[90,92]$. The experimental discrepancies of the inhibitory

Lactoferrin Enhances Host Responses during UTI or excitatory nature of lactoferrin on neutrophils may largely depend on the environmental conditions of the assay, including iron availability [93]. We utilized both native hLf and Fe-Lf in our studies to distinguish the contribution of iron to lactoferrin regulation of neutrophil function. We found that iron saturation of lactoferrin impacted bladder epithelial cell adherence, $E$. coli growth in RPMI, and NET generation, but that lactoferrin enhancement of neutrophil killing and suppression of ROS production was iron-independent which suggests that tissue iron levels will differentially affect neutrophil function. Lastly, we found no direct alteration of lactoferrin on HIF-1a levels in bladder epithelial cells, nor was endogenous lactoferrin influenced in mice deficient in epithelial HIF-1 $\alpha$. Together, these data suggest that the protective role of exogenous hLf in our model was independent of HIF-1a regulation, and that endogenous lactoferrin production by the bladder epithelium is not under regulation by HIF-1 $\alpha$.

Clinical evidence supports the role of lactoferrin in protection against bacterial infections, particularly in the skin and on mucosal surfaces. Humans deficient in neutrophil-specific granules, and thus void of neutrophil-derived lactoferrin, are at an increased risk of recurrent bacterial and fungal infections [94-96]. Genetic models utilizing lactoferrin knockout (Lf KO) mice or transgenic mice expressing hLf have demonstrated mixed roles of lactoferrin for a variety of pathogens. Lf KO mice exhibit impaired ROS production in response to PMA but not bacterial stimuli, and are not more susceptible to systemic S. aureus or P. aeruginosa infection [97]. Conversely, in an oral infection model, Lf $\mathrm{KO}$ mice were more susceptible to alveolar bone loss induced by the oral pathogen Aggregatibacter actinomycetemcomitans [98], and hLftransgenic mice displayed enhanced clearance of systemic S. aureus [99]. In an independently derived mouse strain, Lf KO mice displayed increased expression of inflammatory cytokines in an induced colitis model [100]. Several studies using murine models have demonstrated the protective effect of hLf administration during $E$. coli infection in vivo. Pretreatment of either bovine lactoferrin or hLf increased survival in mice given a lethal dose of E. coli [101]. In a UTI model, oral administration of a single dose of $500 \mu \mathrm{g}$ of hLf at $30 \mathrm{~min}$ postinfection resulted in lower bladder CFU (approx. 100-fold) and urinary leukocytes $24 \mathrm{~h}$ postinfection than in mock-treated controls, but only trace amounts of hLf (well below the MIC) were detected in the urine at $2 \mathrm{~h}$ posttreatment $(<10 \mathrm{ng} / \mathrm{mL})$ [77]. Interestingly, oral administration of bovine lactoferrin in drinking water (estimated as $100 \mathrm{mg}$ / 
mouse/day) does not alter mucosal and systemic immune responses in uninfected mice [102]. In this study, we observed that a single dose of intravesicular hLf $(100 \mu \mathrm{g})$ $1 \mathrm{~h}$ prior to UPEC introduction significantly reduced bladder bacterial burden ( $>1,000$-fold), concurrent with a reduction in infiltrating neutrophils but not other myeloid cells (Fig. 5). Alternatively, in the absence of infection, injection of recombinant lactoferrin into the peritoneal cavity induces both neutrophil and monocyte/macrophage recruitment [83]. Unfortunately, we were unable to distinguish between the contribution of lactoferrin treatment and lower bacterial burden on neutrophil recruitment to the bladder; however, the lack of differences in nonneutrophil CD11b+ populations combined with the striking effects seen in neutrophil in vitro assays led us to conclude that modulation of neutrophil function is a prominent driver of lactoferrin-mediated protection during UTI. An additional limitation of our study was the inability to define the role of endogenous lactoferrin during UTI in vivo. Future studies using resources such as Lf KO mice $[52,100]$ would be informative on the contribution of lactoferrin to urinary tract defense and homeostasis.

In summary, these data demonstrate the protective effects of lactoferrin in UTI through both antiadhesive and immune modulatory activity. Our findings reveal the bladder epithelium as an endogenous source of lactoferrin during UTI, highlighting lactoferrin as a potent therapeutic target of interest in resolving or preventing UTI. Further studies are needed to distinguish the mechanisms by which lactoferrin mediates immune responses in the bladder.

\section{Acknowledgement}

We thank Michael Florio for breeding and maintaining the mice along with the UCSD vivarium staff, and Majid Ghassemian from the UCSD Biomolecular and Proteomics Mass Spectrometry Facility for performing the mass spectroscopy and data analysis.

\section{Statement of Ethics}

Under approval from UC San Diego IRB protocol 070278X, venous blood was obtained under informed consent from healthy adults. Animal experiments were approved by UC San Diego IACUC, protocol S00227M.

\section{Disclosure Statement}

The authors have no conflicts of interest to declare.

\section{Funding Sources}

Studies were supported by NIH grants to V.N. (HL107150; HD090259). K.A.P. was supported through postdoctoral fellowships from University of California Chancellor's Postdoctoral Fellowship Program and the Hartwell Foundation. The UCSD Biomolecular and Proteomics Mass Spectrometry Facility is supported by the NIH shared instrumentation grant No. S10 OD021724 (LUMOS Orbi-Trap).

\section{Author Contributions}

K.A.P., A.E.L., and V.N. conceived and designed experiments. K.A.P., A.E.L., A.D.H., E.R., and J.O. performed experiments. K.A.P., A.E.L, and V.N analyzed and interpreted results. A.E.L, A.D.H, E.R., and J.O. contributed the discussion/manuscript edits. K.A.P. and V.N. drafted the manuscript.

\section{References}

1 Griebling TL. Urologic diseases in America project: trends in resource use for urinary tract infections in women. J Urol. 2005 Apr; 173(4):1281-7.

2 Tandogdu Z, Wagenlehner FM. Global epidemiology of urinary tract infections. Curr Opin Infect Dis. 2016 Feb;29(1):73-9.

3 Anderson BL, Simhan HN, Simons KM, Wiesenfeld HC. Untreated asymptomatic group B streptococcal bacteriuria early in pregnancy and chorioamnionitis at delivery. Am J Obstet Gynecol. 2007;196:524.
4 Schneeberger C, Kazemier BM, Geerlings SE. Asymptomatic bacteriuria and urinary tract infections in special patient groups: women with diabetes mellitus and pregnant women. Curr Opin Infect Dis. 2014 Feb;27(1):108-14.

5 Foxman B. Epidemiology of urinary tract infections: incidence, morbidity, and economic costs. Am J Med. 2002 Jul;113(1 Suppl 1A): 5S-13S.

6 Masajtis-Zagajewska A, Nowicki M. New markers of urinary tract infection. Clin Chim Acta. 2017 Aug;471:286-91.
7 Croxall G, Weston V, Joseph S, Manning G, Cheetham P, McNally A. Increased human pathogenic potential of Escherichia coli from polymicrobial urinary tract infections in comparison to isolates from monomicrobial culture samples. J Med Microbiol. 2011 Jan; 60(Pt 1):102-9.

8 Pitout JD, Nordmann P, Laupland KB, Poirel L. Emergence of Enterobacteriaceae producing extended-spectrum beta-lactamases (ESBLs) in the community. J Antimicrob Chemother. 2005 Jul;56(1):52-9. 
9 Abduzaimovic A, Aljicevic M, Rebic V, Vranic SM, Abduzaimovic K, Sestic S. Antibiotic Resistance in Urinary Isolates of Escherichia coli. Mater Sociomed. 2016 Dec;28(6): 416-9.

10 Alqasim A, Abu Jaffal A, Alyousef AA. Prevalence of Multidrug Resistance and ExtendedSpectrum $\beta$-Lactamase Carriage of Clinical Uropathogenic Escherichia coli Isolates in Riyadh, Saudi Arabia. Int J Microbiol. 2018 Sep; 2018:3026851.

11 Kanno K, Sasaki S, Hirata Y, Ishikawa S, Fushimi K, Nakanishi S, et al. Urinary excretion of aquaporin-2 in patients with diabetes insipidus. N Engl J Med. 1995 Jun;332(23): $1540-5$.

12 Pisitkun T, Shen RF, Knepper MA. Identification and proteomic profiling of exosomes in human urine. Proc Natl Acad Sci USA. 2004 Sep;101(36): 13368-73.

13 Gonzales PA, Pisitkun T, Hoffert JD, Tchapyjnikov D, Star RA, Kleta R, et al. Large-scale proteomics and phosphoproteomics of urinary exosomes. J Am Soc Nephrol. 2009 Feb; 20(2):363-79.

14 Hogan MC, Bakeberg JL, Gainullin VG, Irazabal MV, Harmon AJ, Lieske JC, et al. Identification of Biomarkers for PKD1 Using Urinary Exosomes. J Am Soc Nephrol. 2015 Jul; 26(7):1661-70.

15 Wouters AV. Disaggregated annual health services expenditures: their predictability and role as predictors. Health Serv Res. 1991 Jun; 26(2):247-72.

16 Zhou H, Pisitkun T, Aponte A, Yuen PS, Hoffert JD, Yasuda H, et al. Exosomal Fetuin-A identified by proteomics: a novel urinary biomarker for detecting acute kidney injury. Kidney Int. 2006 Nov;70(10):1847-57.

17 Moon PG, Lee JE, You S, Kim TK, Cho JH, Kim IS, et al. Proteomic analysis of urinary exosomes from patients of early IgA nephropathy and thin basement membrane nephropathy. Proteomics. 2011 Jun;11(12):2459-75.

18 van Balkom BW, Pisitkun T, Verhaar MC, Knepper MA. Exosomes and the kidney: prospects for diagnosis and therapy of renal diseases. Kidney Int. 2011 Dec;80(11):113845.

19 Hiemstra TF, Charles PD, Gracia T, Hester SS, Gatto L, Al-Lamki R, et al. Human urinary exosomes as innate immune effectors. J Am Soc Nephrol. 2014 Sep;25(9):2017-27.

20 Zasloff M. Antimicrobial peptides, innate immunity, and the normally sterile urinary tract. J Am Soc Nephrol. 2007 Nov; 18(11):2810-6.

21 Krzemień G, Pańczyk-Tomaszewska M, Adamczuk D, Kotuła I, Demkow U, Szmigielska A. Neutrophil Gelatinase-Associated Lipocalin: A Biomarker for Early Diagnosis of Urinary Tract Infections in Infants. Adv Exp Med Biol. 2018;1047:71-80.

22 Biragyn A, Ruffini PA, Leifer CA, Klyushnenkova E, Shakhov A, Chertov O, et al. Toll-like receptor 4-dependent activation of dendritic cells by beta-defensin 2. Science. 2002 Nov; 298(5595):1025-9.
23 Valore EV, Park CH, Quayle AJ, Wiles KR, McCray PB Jr, Ganz T. Human beta-defensin-1: an antimicrobial peptide of urogenital tissues. J Clin Invest. 1998 Apr;101(8):163342.

24 Säemann MD, Hörl WH, Weichhart T. Uncovering host defences in the urinary tract: cathelicidin and beyond. Nephrol Dial Transplant. 2007 Feb;22(2):347-9.

25 Weichhart T, Haidinger M, Hörl WH, Säemann MD. Current concepts of molecular defence mechanisms operative during urinary tract infection. Eur J Clin Invest. 2008 Oct;38 Suppl 2:29-38.

26 De Yang, Chen Q, Schmidt AP, Anderson GM, Wang JM, Wooters J, et al. LL-37, the neutrophil granule- and epithelial cell-derived cathelicidin, utilizes formyl peptide receptor-like 1 (FPRL1) as a receptor to chemoattract human peripheral blood neutrophils, monocytes, and T cells. J Exp Med. 2000 Oct;192(7):1069-74.

27 Ingersoll MA, Kline KA, Nielsen HV, Hultgren SJ. G-CSF induction early in uropathogenic Escherichia coli infection of the urinary tract modulates host immunity. Cell Microbiol. 2008 Dec;10(12):2568-78.

28 Carey AJ, Sullivan MJ, Duell BL, Crossman DK, Chattopadhyay D, Brooks AJ, et al. Uropathogenic Escherichia coli Engages CD14Dependent Signaling to Enable Bladder-Macrophage-Dependent Control of Acute Urinary Tract Infection. J Infect Dis. 2016 Feb; 213(4):659-68.

29 Haraoka M, Hang L, Frendéus B, Godaly G, Burdick M, Strieter R, et al. Neutrophil recruitment and resistance to urinary tract infection. J Infect Dis. 1999 Oct;180(4):1220-9.

30 Frendéus B, Godaly G, Hang L, Karpman D, Lundstedt AC, Svanborg C. Interleukin 8 receptor deficiency confers susceptibility to acute experimental pyelonephritis and may have a human counterpart. J Exp Med. 2000 Sep;192(6):881-90.

31 Brooks T, Keevil CW. A simple artificial urine for the growth of urinary pathogens. Lett Appl Microbiol. 1997 Mar;24(3):203-6.

32 Peyssonnaux C, Boutin AT, Zinkernagel AS, Datta V, Nizet V, Johnson RS. Critical role of HIF-1alpha in keratinocyte defense against bacterial infection. J Invest Dermatol. 2008 Aug;128(8):1964-8.

33 Coady A, Ramos AR, Olson J, Nizet V, Patras KA. Tamm-Horsfall protein protects the urinary tract against Candida albicans. Infect Immun. 2018 Oct;86(12):IAI.00451-18.

34 Patras KA, Coady A, Olson J, Ali SR, RamachandraRao SP, Kumar S, et al. Tamm-Horsfall glycoprotein engages human Siglec-9 to modulate neutrophil activation in the urinary tract. Immunol Cell Biol. 2017 Nov;95(10): 960-5.

35 Flores R, Döhrmann S, Schaal C, Hakkim A, Nizet V, Corriden R. The Selective Estrogen Receptor Modulator Raloxifene Inhibits Neutrophil Extracellular Trap Formation. Front Immunol. 2016 Dec;7:566.
36 Clarke TB, Davis KM, Lysenko ES, Zhou AY, Yu Y, Weiser JN. Recognition of peptidoglycan from the microbiota by Nod1 enhances systemic innate immunity. Nat Med. 2010 Feb;16(2):228-31.

37 Pfaffl MW. A new mathematical model for relative quantification in real-time RT-PCR. Nucleic Acids Res. 2001 May;29(9):e45.

38 Lin AE, Beasley FC, Olson J, Keller N, Shalwitz RA, Hannan TJ, et al. Role of Hypoxia Inducible Factor-1 $\alpha$ (HIF-1 $\alpha$ ) in Innate Defense against Uropathogenic Escherichia coli Infection. PLoS Pathog. 2015 Apr;11(4): e1004818.

39 Lin AE, Autran CA, Espanola SD, Bode L, Nizet V. Human milk oligosaccharides protect bladder epithelial cells against uropathogenic Escherichia coli invasion and cytotoxicity. J Infect Dis. 2014 Feb;209(3):389-98.

40 Guttman M, Betts GN, Barnes H, Ghassemian $\mathrm{M}$, van der Geer P, Komives EA. Interactions of the NPXY microdomains of the low density lipoprotein receptor-related protein 1 . Proteomics. 2009 Nov;9(22):5016-28.

41 Paoletti AC, Parmely TJ, Tomomori-Sato C, Sato S, Zhu D, Conaway RC, et al. Quantitative proteomic analysis of distinct mammalian Mediator complexes using normalized spectral abundance factors. Proc Natl Acad Sci USA. 2006 Dec;103(50):18928-33.

42 Eden E, Navon R, Steinfeld I, Lipson D, Yakhini Z. GOrilla: a tool for discovery and visualization of enriched GO terms in ranked gene lists. BMC Bioinformatics. 2009 Feb; 10(1):48

43 Huebner AR, Somparn P, Benjachat T, Leelahavanichkul A, Avihingsanon Y, Fenton RA, et al. Exosomes in urine biomarker discovery. Adv Exp Med Biol. 2015;845:43-58.

44 Masson PL, Heremans JF, Schonne E. Lactoferrin, an iron-binding protein in neutrophilic leukocytes. J Exp Med. 1969 Sep;130(3): 643-58.

45 Zakharova ET, Kostevich VA, Sokolov AV, Vasilyev VB. Human apo-lactoferrin as a physiological mimetic of hypoxia stabilizes hypoxia-inducible factor-1 alpha. Biometals. 2012 Dec;25(6):1247-59.

46 Okumura CY, Hollands A, Tran DN, Olson J, Dahesh S, von Köckritz-Blickwede M, et al. A new pharmacological agent (AKB-4924) stabilizes hypoxia inducible factor-1 (HIF-1) and increases skin innate defenses against bacterial infection. J Mol Med (Berl). 2012 Sep;90(9):1079-89.

47 Singh J, Deshpande M, Suhail H, Rattan R, Giri S. Targeted Stage-Specific Inflammatory microRNA Profiling in Urine During Disease Progression in Experimental Autoimmune Encephalomyelitis: Markers of Disease Progression and Drug Response. J Neuroimmune Pharmacol. 2016 Mar;11(1):84-97.

48 Conde-Vancells J, Rodriguez-Suarez E, Gonzalez E, Berisa A, Gil D, Embade N, et al. Candidate biomarkers in exosome-like vesicles purified from rat and mouse urine samples. Proteomics Clin Appl. 2010 Apr;4(4):416-25. 
49 Leelahavanichkul A, Chancharoenthana W, Eiam-Ong S. Urinary exosomes from a mouse model of chronic tubulointerstitial kidney disease induced by chronic renal ischemiareperfusion injury and nephrectomy. Asian Biomed. 2016;10:447-54.

50 Wang D, Sun W. Urinary extracellular microvesicles: isolation methods and prospects for urinary proteome. Proteomics. 2014 Aug; 14(16):1922-32.

51 Masson PL, Heremans JF. Lactoferrin in milk from different species. Comp Biochem Physiol B. 1971 May;39(1):119-29.

52 Ward PP, Mendoza-Meneses M, Cunningham GA, Conneely OM. Iron status in mice carrying a targeted disruption of lactoferrin. Mol Cell Biol. 2003 Jan;23(1):178-85.

53 Arao S, Matsuura S, Nonomura M, Miki K, Kabasawa K, Nakanishi H. Measurement of urinary lactoferrin as a marker of urinary tract infection. J Clin Microbiol. 1999 Mar;37(3): 553-7.

54 Pan Y, Sonn GA, Sin ML, Mach KE, Shih MC, $\mathrm{Gau} \mathrm{V}$, et al. Electrochemical immunosensor detection of urinary lactoferrin in clinical samples for urinary tract infection diagnosis. Biosens Bioelectron. 2010 Oct;26(2):649-54.

55 Abrink M, Larsson E, Gobl A, Hellman L. Expression of lactoferrin in the kidney: implications for innate immunity and iron metabolism. Kidney Int. 2000 May;57(5):2004-10.

56 Botelho MC, Ribeiro R, Vale N, Oliveira P, Medeiros R, Lopes C, et al. Inactivation of estrogen receptor by Schistosoma haematobium total antigen in bladder urothelial cells. Oncol Rep. 2012 Feb;27(2):356-62.

57 Vogel HJ. Lactoferrin, a bird's eye view. Biochem Cell Biol. 2012 Jun;90(3):233-44.

58 Glimvall P, Wickström C, Jansson H. Elevated levels of salivary lactoferrin, a marker for chronic periodontitis? J Periodontal Res. 2012 Oct;47(5):655-60.

59 Spear GT, Kendrick SR, Chen HY, Thomas TT, Bahk M, Balderas R, et al. Multiplex immunoassay of lower genital tract mucosal fluid from women attending an urban STD clinic shows broadly increased IL1ß and lactoferrin. PLoS One. 2011 May;6(5):e19560.

60 Kijlstra A, Jeurissen SH, Koning KM. Lactoferrin levels in normal human tears. Br J Ophthalmol. 1983 Mar;67(3):199-202.

61 Maacks S, Yuan HZ, Wood WG. Development and evaluation of luminescence-based sandwich assay for plasma lactoferrin as a marker for sepsis and bacterial infections in paediatric medicine. J Biolumin Chemilumin. 1989;3(4):221-6.

62 Karav S. Selective deglycosylation of lactoferrin to understand glycans' contribution to antimicrobial activity of lactoferrin. Cell Mol Biol. 2018 Jun;64(9):52-7.

63 Conesa C, Rota MC, Pérez MD, Calvo M, Sánchez L. Antimicrobial activity of recombinant human lactoferrin from Aspergillus awamori, human milk lactoferrin and their hydrolysates. Eur Food Res Technol. 2008;228(2): 205-11.
64 Lee HY, Park JH, Seok SH, Baek MW, Kim DJ, Lee $\mathrm{BH}$, et al. Potential antimicrobial effects of human lactoferrin against oral infection with Listeria monocytogenes in mice. J Med Microbiol. 2005 Nov;54(Pt 11):1049-54.

65 Arnold RR, Brewer M, Gauthier JJ. Bactericidal activity of human lactoferrin: sensitivity of a variety of microorganisms. Infect Immun. 1980 Jun;28(3):893-8.

66 Wakabayashi H, Abe S, Okutomi T, Tansho $\mathrm{S}$, Kawase K, Yamaguchi H. Cooperative antiCandida effects of lactoferrin or its peptides in combination with azole antifungal agents. Microbiol Immunol. 1996;40(11):821-5.

67 Kuipers ME, de Vries HG, Eikelboom MC, Meijer DK, Swart PJ. Synergistic fungistatic effects of lactoferrin in combination with antifungal drugs against clinical Candida isolates. Antimicrob Agents Chemother. 1999 Nov;43(11):2635-41.

68 Grammatikova NE, Rezvan SP, Nemtsova ER, Bezborodova OA, Tutykhina IL, Naroditskiǐ $\mathrm{BS}$, et al. [In vitro study of antimicrobial activity of lactoferrins from various sources]. Antibiot Khimioter. 2010;55(7-8):4-9.

69 Hutchens TW, Henry JF, Yip TT, Hachey DL, Schanler RJ, Motil KJ, et al. Origin of intact lactoferrin and its DNA-binding fragments found in the urine of human milk-fed preterm infants. Evaluation by stable isotopic enrichment. Pediatr Res. 1991 Mar;29(3):243-50.

70 Troost FJ, Steijns J, Saris WH, Brummer RJ. Gastric digestion of bovine lactoferrin in vivo in adults. J Nutr. 2001 Aug;131(8):2101-4.

71 de Araújo AN, Giugliano LG. Lactoferrin and free secretory component of human milk inhibit the adhesion of enteropathogenic Escherichia coli to HeLa cells. BMC Microbiol. 2001;1(1):25.

72 O'Halloran F, Beecher C, Chaurin V, Sweeney T, Giblin L. Lactoferrin affects the adherence and invasion of Streptococcus dysgalactiae ssp. dysgalactiae in mammary epithelial cells. J Dairy Sci. 2016 Jun;99(6):4619-28.

73 Chen R, Cole N, Dutta D, Kumar N, Willcox MD. Antimicrobial activity of immobilized lactoferrin and lactoferricin. J Biomed Mater Res B Appl Biomater. 2017 Nov; 105(8):26127.

74 Elass-Rochard E, Legrand D, Salmon V, Roseanu A, Trif M, Tobias PS, et al. Lactoferrin inhibits the endotoxin interaction with CD14 by competition with the lipopolysaccharidebinding protein. Infect Immun. $1998 \mathrm{Feb}$ 66(2):486-91.

75 Almeida RA, Dego OK, Headrick SI, Lewis MJ, Oliver SP. Role of Streptococcus uberis adhesion molecule in the pathogenesis of Streptococcus uberis mastitis. Vet Microbiol. 2015 Sep;179(3-4):332-5.

76 Rowe MC, Withers HL, Swift S. Uropathogenic Escherichia coli forms biofilm aggregates under iron restriction that disperse upon the supply of iron. FEMS Microbiol Lett. 2010 Jun;307(1):102-9.
77 Håversen LA, Engberg I, Baltzer L, Dolphin G, Hanson LA, Mattsby-Baltzer I. Human lactoferrin and peptides derived from a surfaceexposed helical region reduce experimental Escherichia coli urinary tract infection in mice. Infect Immun. 2000 Oct;68(10):581623.

78 Håversen L, Ohlsson BG, Hahn-Zoric M, Hanson LA, Mattsby-Baltzer I. Lactoferrin down-regulates the LPS-induced cytokine production in monocytic cells via NF-kappa B. Cell Immunol. 2002 Dec;220(2):83-95.

79 Valenti P, Rosa L, Capobianco D, Lepanto MS, Schiavi E, Cutone A, et al. Role of Lactobacilli and Lactoferrin in the Mucosal Cervicovaginal Defense. Front Immunol. 2018 Mar;9:376.

80 Kruzel ML, Harari Y, Mailman D, Actor JK, Zimecki M. Differential effects of prophylactic, concurrent and therapeutic lactoferrin treatment on LPS-induced inflammatory responses in mice. Clin Exp Immunol. 2002 Oct;130(1):25-31.

81 He J, Furmanski P. Sequence specificity and transcriptional activation in the binding of lactoferrin to DNA. Nature. 1995 Feb; 373(6516):721-4.

82 Kruzel ML, Actor JK, Boldogh I, Zimecki M. Lactoferrin in health and disease. Postepy Hig Med Dosw (Online). 2007;61:261-7.

83 de la Rosa G, Yang D, Tewary P, Varadhachary A, Oppenheim JJ. Lactoferrin acts as an alarmin to promote the recruitment and activation of APCs and antigen-specific immune responses. J Immunol. 2008 May; 180(10): 6868-76.

84 Lima MF, Kierszenbaum F. Lactoferrin effects of phagocytic cell function. II. The presence of iron is required for the lactoferrin molecule to stimulate intracellular killing by macrophages but not to enhance the uptake of particles and microorganisms. J Immunol. 1987 Sep;139(5):1647-51.

85 Lutaty A, Soboh S, Schif-Zuck S, ZeituniTimor O, Rostoker R, Podolska MJ, et al. A $17-\mathrm{kDa}$ Fragment of Lactoferrin Associates With the Termination of Inflammation and Peptides Within Promote Resolution. Front Immunol. 2018 Mar;9:644.

86 Schauer C, Janko C, Munoz LE, Zhao Y, Kienhöfer D, Frey B, et al. Aggregated neutrophil extracellular traps limit inflammation by degrading cytokines and chemokines. Nat Med. 2014 May;20(5):511-7.

87 Okubo K, Kamiya M, Urano Y, Nishi H, Herter JM, Mayadas T, et al. Lactoferrin Suppresses Neutrophil Extracellular Traps Release in Inflammation. EBioMedicine. 2016 Aug; 10: 204-15.

88 Baveye S, Elass E, Mazurier J, Legrand D. Lactoferrin inhibits the binding of lipopolysaccharides to L-selectin and subsequent production of reactive oxygen species by neutrophils. FEBS Lett. 2000 Mar;469(1):5-8. 
89 Meera R, Anand S, Ramesh CV, Puvanakrishnan R. Inhibition of neutrophil derived lysosomal enzymes and reactive oxygen species by a novel tetrapeptide. Inflamm Res. 1999 Sep; 48(9):479-84.

90 Gahr M, Speer CP, Damerau B, Sawatzki G. Influence of lactoferrin on the function of human polymorphonuclear leukocytes and monocytes. J Leukoc Biol. 1991 May;49(5): $427-33$.

91 Wong SH, Francis N, Chahal H, Raza K, Salmon M, Scheel-Toellner D, et al. Lactoferrin is a survival factor for neutrophils in rheumatoid synovial fluid. Rheumatology (Oxford). 2009 Jan;48(1):39-44.

92 Pruzanski W, Saito S. The influence of natural and synthetic cationic substances on phagocytic activity of human polymorphonuclear cells. An alternative pathway of phagocytic enhancement. Exp Cell Res. 1978 Nov;117(1): $1-13$.

93 Levay PF, Viljoen M. Lactoferrin: a general review. Haematologica. 1995 May-Jun;80(3): 252-67.
94 Breton-Gorius J, Mason DY, Buriot D, Vilde $\mathrm{JL}$, Griscelli C. Lactoferrin deficiency as a consequence of a lack of specific granules in neutrophils from a patient with recurrent infections. Detection by immunoperoxidase staining for lactoferrin and cytochemical electron microscopy. Am J Pathol. 1980 May;99(2): 413-28.

95 Lomax KJ, Gallin JI, Rotrosen D, Raphael GD, Kaliner MA, Benz EJ Jr, et al. Selective defect in myeloid cell lactoferrin gene expression in neutrophil specific granule deficiency. J Clin Invest. $1989 \mathrm{Feb}$;83(2):514-9.

96 Raphael GD, Davis JL, Fox PC, Malech HL, Gallin JI, Baraniuk JN, et al. Glandular secretion of lactoferrin in a patient with neutrophil lactoferrin deficiency. J Allergy Clin Immunol. 1989 Dec;84(6 Pt 1):914-9.

97 Ward PP, Mendoza-Meneses M, Park PW, Conneely OM. Stimulus-dependent impairment of the neutrophil oxidative burst response in lactoferrin-deficient mice. Am J Pathol. 2008 Apr;172(4):1019-29.
98 Velusamy SK, Ganeshnarayan K, Markowitz $\mathrm{K}$, Schreiner H, Furgang D, Fine DH, et al. Lactoferrin knockout mice demonstrates greater susceptibility to Aggregatibacter actinomycetemcomitans-induced periodontal disease. J Periodontol. 2013 Nov;84(11): 1690-701.

99 Guillén C, McInnes IB, Vaughan DM, Kommajosyula S, Van Berkel PH, Leung BP, et al. Enhanced Th1 response to Staphylococcus aureus infection in human lactoferrin-transgenic mice. J Immunol. 2002 Apr;168(8): 3950-7.

100 Ye Q, Zheng Y, Fan S, Qin Z, Li N, Tang A, et al. Lactoferrin deficiency promotes colitis-associated colorectal dysplasia in mice. PLoS One. 2014 Jul;9(7):e103298.

101 Zagulski T, Lipiński P, Zagulska A, Broniek S, Jarzabek Z. Lactoferrin can protect mice against a lethal dose of Escherichia coli in experimental infection in vivo. Br J Exp Pathol. 1989 Dec;70(6):697-704.

102 Sfeir RM, Dubarry M, Boyaka PN, Rautureau $\mathrm{M}$, Tomé $\mathrm{D}$. The mode of oral bovine lactoferrin administration influences mucosal and systemic immune responses in mice. J Nutr. 2004 Feb;134(2):403-9. 